\title{
PATTERNS OF TRADE IN THE MARKET FOR USED DURABLES: THEORY AND EVIDENCE
}

\author{
Robert H. Porter \\ Peter Sattler
}

Working Paper 7149

http://www.nber.org/papers/w7149

\author{
NATIONAL BUREAU OF ECONOMIC RESEARCH \\ 1050 Massachusetts Avenue \\ Cambridge, MA 02138 \\ May 1999
}

We received helpful comments from Severin Borenstein, Ray Deneckere, and from the participants in a number of seminars. Porter received financial support from the National Science Foundation. All opinions expressed are those of the authors and not those of the National Bureau of Economic Research.

(C) 1999 by Robert H. Porter and Peter Sattler. All rights reserved. Short sections of text, not to exceed two paragraphs, may be quoted without explicit permission provided that full credit, including $(C$ notice, is given to the source. 
Patterns of Trade in the Market for Used

Durables: Theory and Evidence

Robert H. Porter and Peter Sattler

NBER Working Paper No. 7149

May 1999

JEL No. D42, L62

\section{ABSTRACT}

The consumption value of a durable good diminishes as it ages due to physical deterioration and consumers' preference for the new. We develop a model of consumer specialization and trade in the market for used durables based on imperfect substitutability. Imperfect substitutability across vintages is reflected in a declining market price over time. Heterogeneous consumers maximize utility by specializing in durables of differing ages. Consumers must trade to acquire their preferred vintage each period. When there are transaction costs in the secondhand market, the volume of trade due to specialization increases with imperfect substitutability. We examine the determinants of vehicle ownership transfers in Illinois, a measure of trade volume. Observed patterns of trade across automobile model years are consistent with our model, and inconsistent with a model of adverse selection.

Robert H. Porter Department of Economics Northwestern University 2003 Sheridan Road

Evanston, IL 60208-2600 and NBER r-porter@nwu.edu
Peter Sattler

School of Management

215 Jacobs Hall, North Campus

SUNY Buffalo

Buffalo, NY 14260-4000

psattler@buffalo.edu 


\section{Introduction}

The used car market has been growing rapidly, because of fleet sales, leasing, improved reliability of used vehicles, and other related phenomena. (See, for example, "Stigma gone, used vehicles defy the system," Advertising Age 68(14) S2, April 7, 1997.) The growth of the secondhand market, together with increases in car longevity (Hamilton and Macauley, 1998), has affected the market for new automobiles. Used goods compete with new goods, and the secondhand market is an important factor in the market for durables.

A used durable is often traded for one of three reasons. First, owners may sell if the good they acquired is of inferior quality. Akerlof (1970) models the adverse selection problem that results when only the owner knows whether quality is substandard in his famous "lemons" paper. He shows that the secondhand market could shut down because of adverse selection. Hendel and Lizzeri (1997) examine the effects of adverse selection in a framework similar to ours. They argue that "an undesirable feature of Akerlof style models of adverse selection is that ownership of used cars is independent of preferences, and therefore ad hoc. ... We show that ... the used market never shuts down and that the volume of trade can be quite substantial even in cases with severe informational asymmetries. ... We show that unreliable car brands have steeper price declines and lower volumes of trade." (p. i)

Second, there may be exogenous changes in owners' preferences that reduce their demand for the product. Bulow (1982, p. 318) provides the following example: “...consider the demand for baby carriages. In 1954 my parents had a high demand for one unit. In the current period their demand is zero, while someone else is doing the demanding. ... If the demanders remained the same each period, there would be no need for secondhand transactions."

We consider a third reason in this paper. Transactions may occur because the quality of a durable deteriorates over time, so that current owners sell in order to update to their preferred quality. Bond (1982) notes that the quality or quantity of the services a 
durable good provides may deteriorate with age. Alternatively, either the level of required maintenance or the probability of failure may increase. Many used car sales appear to arise from this consideration, in which the deterioration in a car's perceived quality is common knowledge. For example, some consumers trade in their cars at regular intervals, such as every three years. However, this motive for trade is often ignored in models of secondhand markets that focus on the first two motives.

We model a durable good market where perceived depreciation of the used good induces transactions. Our model incorporates vertical differentiation into a standard durable good model in which the quality of the durable good deteriorates as it ages. A monopolist sells durables to a succession of overlapping generations of heterogeneous consumers, who differ in their willingness to pay for the services provided by the durable good. We assume consumers have complete information concerning quality changes over time. A motive for secondhand trade arises from the heterogeneity in preferences rather than random quality. Transaction costs associated with secondhand sales play a role in the consumers' decisions. Each period, consumers assess the quality of the durable they own. If the gain in utility from updating their holdings, net of prices, exceeds transaction costs, consumers sell their used goods in the secondhand market and replace them with durables of the preferred quality. Related models of durable goods markets with heterogeneous consumers and known depreciation (or quality improvement) across vintages are considered by Fudenberg and Tirole (1998), Hendel and Lizzeri (1997) and Waldman (1993, 1996). Hendel and Lizzeri discuss a model with two durable products that yields comparative statics predictions similar to the results we obtain.

The difference between trade due to changes in consumers' preferences and trade occurring because the good changes may seem minor, as may the distinction between known and random (but privately observed by the owner) changes in the quality of the good. However, the three motives for trade have different predictions concerning patterns of trade in durable markets. We show that under our assumptions car models that depreciate relatively quickly have steeper price declines, but higher volumes of trade, because the potential gains from trade between heterogeneous consumers are greater. 
This predicted pattern is opposite to that of the adverse selection model of Hendel and Lizzeri (1997), as described above.

Some used car models are relatively poor substitutes for new models, and prices in the secondhand market reflect this information. We exploit differences across model/years in price declines over time. We examine vehicle title transfers recorded by the Illinois Secretary of State, price data from the National Auto Dealers Association, and quality data from Consumer Reports. Ownership transfers for more than 104,000 passenger cars and pick-up trucks in Illinois from model years 1986, 1987 and 1988 are traced from the dealer's lot to the titleholders on December 15, 1994. Quality, intensity of use (odometer miles) and manufacturer specific effects are controlled for. The predictions of our model are confirmed by the data. We find that the rate of decline of a used car model's prices is negatively and significantly correlated with the length of ownership tenure, or with the likelihood that the original owner does not sell the vehicle before the end of the sample period. There are also significant manufacturer, mileage, and quality effects on ownership tenure.

The used market performs a valuable function for consumers and the manufacturer. The availability of low quality, low price goods permits low valuation consumers who would otherwise not participate in the market to own the good, albeit perhaps a clunker. A market for used goods permits higher valuation consumers to trade in their older vehicle for a newer one. If the secondhand market did not exist, these consumers might instead scrap their used car, or refrain from trade and hold their vehicle for a longer period. The used market allows high valuation consumers to maintain ownership of their preferred vintage or quality.

A manufacturer of new durables will benefit from the used market in several ways. (Varian (1997) makes this point in a model of a market for information goods.) The number of units sold increases because low valuation consumers who would not purchase otherwise buy used goods. Low quality durables are traded in the secondhand market that the firm might not be able to supply economically. An extreme example is an old car that 
sells for a few hundred dollars. The manufacturer is probably unable to produce a new good that cheaply, as the vehicle sells for little more than its scrap value. The more efficient the secondhand market, the higher the trade-in value of used cars, and the more likely older cars can be acquired by low valuation consumers at low cost. Finally, without a used car market, the firm would be tempted to lower price and sell to the lower valuation consumers. A monopolist of durable goods faces competition in the current period from past and expected future production. Coase (1972) conjectures that if a monopolist cannot credibly commit to future production levels, it would price at marginal cost. Such a firm may want to promote a secondhand market that is as frictionless as possible. ${ }^{1}$ Bond and Samuelson (1984) consider a Coasian pricing model where the durable has a finite lifetime and consumers make replacement purchases. They assume consumers are homogeneous, and so there is no role for secondhand markets.

Benjamin and Kormendi (1974) argue that a monopolist can maintain market power, despite an inability to commit to future production, by restricting the used market. Liebowitz (1982) considers a two period model with independent and unequal first and second period demands. He argues that unequal demand is the "key to the paradox" (p. 820) and that in this case a monopolist benefits from an unrestricted used market. Miller (1974) uses the used textbook market as an example and obtains the opposite result. In a two period model with constant returns to scale in production, he finds no support for the belief that textbook publishers rush out new editions in order to solve the "problem" and reduce secondhand sales. A limitation of the approach taken by Benjamin and Kormendi, Liebowitz, and Miller is that in their models consumers do not choose between new and used goods in the same period. The coexistence of new and used goods in the market is essential to the consumer decision process that we consider.

One of our goals is to quantify patterns of trade in durable markets. Bond (1983) tests whether trade in used trucks can be explained by heterogeneity in firm cost functions.

\footnotetext{
${ }^{1}$ See, for example, “Ford Buys a Used Car Concept,” Business Week, 3506, December 16, 1996.
} 
Large firms face higher labor costs but are able to obtain lower interest rates. Hence, maintenance of older vehicles is more expensive for large firms than for small firms with lower labor costs. Bond considers a static model in which the manufacturer does not choose price. Bond's empirical work compares new and used durables. In our model, quality varies with the age of the durable, the model nameplate and the manufacturer. Bond (1982) does not find evidence of adverse selection, and he conjectures that institutions have developed to verify quality, as Akerlof suggested. In contrast, Genesove (1992) finds some evidence of adverse selection in wholesale automobile auctions, where interdealer trading occurs.

Purohit (1992) studies changes in used car prices as a function of innovations in the market for new automobiles. He finds that when a model is discontinued, or when the manufacturer extensively redesigns a model, the corresponding used prices fall more than would be otherwise expected.

The paper proceeds as follows. In section II we describe the model and some testable predictions. The data set is described section III. Empirical results are presented in section IV, and we conclude in section V.

\section{A Simple Model}

In this section, we describe a simple discrete time model of equilibrium in a secondhand market for a durable good. We begin with a frictionless environment in which every durable good is traded in every period. We then introduce transaction costs in the secondhand market that are borne by the seller, and describe how the pattern of trade differs across durable goods with varying degrees of depreciation. We consider a model with a single infinitely lived firm and a succession of overlapping generations of twoperiod lived consumers. The durable good also lasts for two periods. Consumers value the durable good for the flow of services the good provides during its life, as in Hirshleifer (1971). If the service flow diminishes over time, the used durable good is an imperfect substitute for a new good. The service flow, the benefit from using the durable, includes 
both physical output (transportation or production) and other less tangible benefits that often decline with age (such as reliability, new technology, and the envy of neighbors).

One common modeling assumption concerning a durable's flow of services is that of one hoss shay: an L period lived durable is a perfect substitute for a new good through its useful life, but in period L+1 the good falls apart and becomes useless. ${ }^{2}$ One hoss shay is a convenient modeling assumption, but it assumes away a potential motive for trade in durables in that quality is independent of age. Another necessary condition for trade in used durables is consumer heterogeneity in willingness to pay for quality. Under these conditions, secondhand trade is an integral part of a vertically differentiated product market. The used market permits consumers of heterogeneous preferences for quality to update to their preferred vintage by selling an older good and buying a newer model.

\section{II.1. A Model Without Transaction Costs}

We first present a model without transaction costs. The effects of transaction costs in the secondhand market are studied in Section II.2.

The durable good provides a flow of services for two periods, in the amounts $s_{1}$ and $s_{2}$ in the first and second periods of its life. The good has no scrap value, and scrappage is assumed to be costless. We normalize $s_{1}$ and $s_{2}$ to fix the discounted flow of services, given a discount factor $\beta$ :

$$
\mathrm{s}_{1}+\beta \mathrm{s}_{2}=1
$$

If new goods are preferred to used, $s_{1} \geq s_{2} \cdot{ }^{3}$ If the used good is a perfect substitute for the

\footnotetext{
2 The term is from The Deacon's Masterpiece by Oliver Wendell Holmes:

Have you heard of the wonderful one hoss shay

That was built in such a logical way

It ran a hundred years to the day?

And then of a sudden -- ah, but stay, ...

3 There is no loss of generality in this assumption. If $s_{2}>s_{1}$, the analysis could proceed with the names reversed. In that case high valuation consumers would specialize in the used good. Low valuation consumers would buy the good new and "break it in".
} 
new, then $s_{1}=s_{2}$; this case of perfect substitutes is the "One Hoss Shay" assumption. At the other extreme, if the good is a consumption good the used durable is worthless, implying $\mathrm{s}_{1}=1$ and $\mathrm{s}_{2}=0$.

\section{The Firm's Maximization Problem}

A monopolist produces at each date a durable good that has a useful life of two periods. The monopolist seeks to maximize the present value of its profits:

$$
\Pi=\sum_{t=0}^{\infty} \beta^{t}\left(P_{1, t}-c\right) Q_{t},
$$

where $\mathrm{P}_{1, t}$ and $\mathrm{Q}_{\mathrm{t}}$ are the price and quantity of the new good in period $\mathrm{t}, \mathrm{c}$ is the constant marginal cost, and $\beta$ is the firm's discount factor. The market price of a used good in the second of period of its life at time $t$ is denoted $\mathrm{P}_{2, t}$. A three period old good is worthless, and hence $\mathrm{P}_{3, \mathrm{t}}$ is zero. We assume markets clear and no valuable goods are scrapped. Therefore, the quantity of used goods available at time $\mathrm{t}$ is $\mathrm{Q}_{\mathrm{t}-1}$. Given a production sequence $\mathrm{Q}_{t}$ for all $t$, market equilibrium will imply a sequence of new and used prices, $\mathrm{P}_{1, t}$ and $\mathrm{P}_{2, \mathrm{t}}$ for all $\mathrm{t}$. In order to solve for the market clearing price sequence, we must describe the problem facing consumers.

\section{Consumers' Preferences and Market Clearing}

Assume that each period a cohort of two period lived consumers enters the market. The cohort that enters the market in period $t$ is said to be active in periods $t$ and $t+1$. Consumers discount at the same rate as the firm. Consumer heterogeneity within a cohort is captured by $\theta$, the marginal willingness to pay for quality, which is distributed uniformly over $[0, \Theta]$ with density $1 / 2$. The total number of active consumers in any period is $\Theta$. An active consumer of type $\theta$ derives net utility from a durable of vintage $i$ in period $\mathrm{t}$ as follows:

$$
u(i, \theta, t)=\theta s_{i}-\left(P_{i, t}-\beta P_{i+1, t+1}\right) .
$$

Here $P_{i, t}-\beta P_{i+1, t+1}$ is the implicit rental price of using a durable of vintage $i$, namely the price of the good today less the present value of its resale price next period. We 
normalize utility so consumers derive zero net utility if they decide to stay out of the market. A consumer in cohort $\mathrm{t}$ chooses a durable vintage each period to maximize the present value of utility across the two periods in which he or she is active:

$$
\mathrm{u}\left(\mathrm{i}_{\mathrm{t}}, \theta, \mathrm{t}\right)+\beta \mathrm{u}\left(\mathrm{i}_{\mathrm{t}+1}, \theta, \mathrm{t}+1\right) .
$$

Consumers implicitly have quasi-linear utility, which depends on the discounted service flows from durable consumption and on end of life wealth.

Optimal consumer choices in any given period fall into one of three categories. High valuation consumers buy a new durable, intermediate valuation consumers buy used durables, and low valuation consumers do not participate in the market, as depicted in Figure 1. We assume that quantities and prices are such that each set of consumers is non-empty. A consumer who buys a durable good of a given vintage must obtain higher net utility than under the alternatives. Absent market frictions or borrowing constraints, consumers face a static optimization problem each period they are in the market, and optimal behavior in a given period is the same function of their type for both active cohorts of consumers.

Denote the consumer indifferent between new and used goods at time t by $\theta_{1, t}$. For this marginal consumer, the following incentive compatibility constraint holds:

$$
\theta_{1, t} \mathrm{~s}_{1}-\left(\mathrm{P}_{1, t}-\beta \mathrm{P}_{2, t+1}\right)=\theta_{1, \mathrm{~s}} \mathrm{~s}_{2}-\mathrm{P}_{2, \mathrm{t}}
$$

The consumer compares the gain in utility from consuming a new good to the higher price, net of the discounted resale value of the new good. We assume that consumers have perfect foresight with respect to future prices.

Denote the consumer indifferent between buying a used good and not participating in the market at time t by $\theta_{2, t}$. For this consumer, a participation constraint binds:

$$
\theta_{2, \mathrm{~s}} \mathrm{~S}_{2}-\mathrm{P}_{2, \mathrm{t}}=0 .
$$

Given these two constraints and assuming market clearing, the quantity of goods in the market can be expressed as a function of the maximum reservation value, $\Theta$, and the identity of the marginal consumers. Consumers with preference types in the interval $\left[\theta_{1, t}\right.$, 
$\Theta]$ purchase the new good. Similarly, consumers in the interval $\left[\theta_{2, t}, \theta_{1, t}\right)$ purchase used goods. Therefore, market clearing in new goods at time $\mathrm{t}$ and used goods at time $\mathrm{t}+1$ implies, for every period $\mathrm{t}$,

$$
\mathrm{Q}_{\mathrm{t}}=\Theta-\theta_{1, \mathrm{t}}=\theta_{1, \mathrm{t}+1}-\theta_{2, \mathrm{t}+1} \text {. }
$$

\section{Profit Maximizing Production}

The first step in solving the firm's maximization problem is to derive the inverse demand curve. By substituting the expressions for the marginal consumers into the market clearing condition, we can express inverse demand as:

$$
P_{1, t}=\Theta-Q_{t}-s_{2} Q_{t-1}-\beta s_{2} Q_{t+1} .
$$

The price of a new good is a function of the quantity of used goods on the market, $\mathrm{Q}_{\mathrm{t}-1}$, and how much is produced next period, $\mathrm{Q}_{\mathrm{t}+1}$. The larger the number of used goods on the market, the lower the price of used goods, and the less consumers are willing to pay for a new good. The more the firm produces next period, the lower will be the price of new and used goods next period, and hence the lower the resale price of a current new good when it becomes used next period. Therefore, the higher next period production, the higher the implicit rental price of a new good this period, and the less consumers are willing to pay for new goods this period.

We can now describe the steady state solution to the firm's maximization problem, under the assumption that it can commit to a sequence of outputs. If the firm cannot commit, the steady state solution has similar comparative statics properties, but there is more production each period.

When there are no transaction costs, the steady state solution to the firm's maximization problem is to produce the quantity

$$
Q^{*}=\frac{\Theta-c}{2\left(1+(1+\beta) s_{2}\right)}
$$

in each period and sell it at the price

$$
P^{*}=\frac{\Theta+c}{2} \text {. }
$$


When quantity $\mathrm{Q}^{*}$ is produced each period, the firm's profit will be $\Pi=\frac{(\Theta-c)^{2}}{4\left(1+(1+\beta) s_{2}\right)}$.

These expressions follow from the first order conditions with respect to $\mathrm{Q}_{\mathrm{t}}$. The steady state $\mathrm{Q}^{*}$ is obtained from the first order condition, evaluated where $\mathrm{Q}_{\mathrm{t}}$ equals $\mathrm{Q}^{*}$ for all $\mathrm{t}$. In the case of one hoss shay, there are multiple steady states. For example, the firm could produce $2 \mathrm{Q}^{*}$ every other period, and nothing in the remaining periods. However, whenever a used good is an imperfect substitute for a new good, so that $s_{2}<s_{1}$, the unique steady state entails producing $\mathrm{Q}^{*}$ every period.

Note that, given the normalization of discounted service flows, steady state profits are a decreasing function of $s_{2}$. The monopolist prefers that the durable deteriorates quickly, or that new and used goods are relatively imperfect substitutes.

\section{II.2. A Model with Transaction Costs}

In the previous section we showed that when there are no transaction costs, consumers face a static optimization problem each period. In the steady state, $\mathrm{Q}^{*}$ consumers "update" by purchasing a new good each period, and on the other side of the market $\mathrm{Q}^{*}$ consumers purchase used goods. However, transaction costs are a part of any secondhand market. We assume that a transaction cost $\mathrm{T}$ must be borne by the seller of a used good. For example, a seller might have to place a newspaper advertisement, pay to have the quality of the used durable certified, or trade in the durable to a dealer at the wholesale price.

In the presence of transaction costs, consumers who buy a new good when they are young do not necessarily sell it at the end of the period. Some consumers are better off holding the good for its entire useful life. We now derive comparative statics predictions concerning the volume of trade in used durables in the presence of this kind of market friction. 
Assume that in a secondhand transaction a cost $\mathrm{T}$ is borne by the seller. Each cohort of consumers again has preferences distributed uniformly over $[0, \Theta]$ with density $1 / 2$. Since two cohorts are active any time, the total number of consumers remains $\Theta$, but it is important to distinguish between the behavior of the two active cohorts. The other modeling assumptions remain the same.

Under these assumptions, consumers will segment into four groups. Some buy a new durable each period and sell them on the used market, some buy a new durable and keep it for two periods, some buy a used good each period, and some do not participate in the market, as shown in Figure 2. Denote the consumers in cohort $t$ who are indifferent between the first and second option, the second and third, and the third and fourth as $\operatorname{types} \tilde{\theta}_{1, t}, \tilde{\theta}_{2, \mathrm{t}}$ and $\tilde{\theta}_{3, \mathrm{t}}$ respectively.

Consider a consumer in the cohort that appears in period t. The net utility from buying a new durable each period is given by:

$$
(1+\beta) \theta s_{1}-P_{1, t}-\beta P_{1, t+1}+\beta P_{2, t+1}+\beta^{2} P_{2, t+2}-\beta(1+\beta) T .
$$

This consumer receives the discounted service flow from having a new car in each period and pays the new car price each period, but recoups the next period used car price net of transaction costs.

The net utility from buying a durable in period $t$ and keeping it in period $t+1$ is not affected directly by transaction costs:

$$
\theta \mathrm{s}_{1}-\mathrm{P}_{1, \mathrm{t}}+\beta \theta \mathrm{s}_{2}
$$

Thus the marginal consumer $\tilde{\theta}_{1, t}$, who buys a new car in period $t$ and is indifferent between holding it for another period versus selling it and buying another new car, is defined implicitly by:

$$
\theta \mathrm{s}_{1}-\mathrm{P}_{1, \mathrm{t}+1}+\mathrm{P}_{2, \mathrm{t}+1}+\beta \mathrm{P}_{2, \mathrm{t}+2}-(1+\beta) \mathrm{T}=\theta \mathrm{s}_{2}
$$


The net utility from buying a used durable each period remains the same as before.

The identity of the marginal consumer $\tilde{\theta}_{3, t}$, who is indifferent between buying a used good in period $\mathrm{t}$ and staying out of the market, is given by the participation constraint in the model without transaction costs. This marginal consumer is the same for both active cohorts.

Finally, the marginal consumer $\tilde{\theta}_{2, t}$, who is indifferent between buying a new car in period $t$ and keeping it for two periods, as opposed to buying a used car each period, is given by:

$$
\theta s_{1}-P_{1, t}=\theta s_{2}-P_{2, t}-\beta P_{2, t+1}
$$

This consumer compares the gain in service flows in the first period to the difference between buying a new durable in period $t$ and buying a used good each period.

In period $t$, new goods are bought by old consumers on the interval $\left[\tilde{\theta}_{1, t-1}, \Theta\right]$, and by young consumers on $\left[\tilde{\theta}_{2, \mathrm{t}}, \Theta\right]$. Market clearing requires that:

$$
Q_{t}=\left(\Theta-\tilde{\boldsymbol{\theta}}_{2, t}\right) / 2+\frac{\left(\Theta-\tilde{\boldsymbol{\theta}}_{1, t-1}\right)}{2} .
$$

Used goods in period $t$ are held by old consumers on $\left[\tilde{\theta}_{3, t}, \tilde{\theta}_{1, t-1}\right)$, and by young consumers on $\left[\tilde{\theta}_{3, t}, \tilde{\theta}_{2, t}\right)$. Market clearing requires that:

$$
Q_{t-1}=\frac{\left(\tilde{\boldsymbol{\theta}}_{1, t-1}-\tilde{\boldsymbol{\theta}}_{3, t}\right)}{2}+\left(\tilde{\boldsymbol{\theta}}_{2, t}-\tilde{\boldsymbol{\theta}}_{3, t}\right) / 2 .
$$

When there are transaction costs $\mathrm{T}$ in the used market borne by the seller, the inverse demand curve for the firm will be:

$$
P_{1, t}=\Theta-Q_{t}-s_{2} Q_{t-1}-\beta s_{2} Q_{t+1}-(1+\beta) T / 2 .
$$


For the manufacturer, the presence of the transaction costs $\mathrm{T}$ in the used market is equivalent to an increase in its marginal cost by $(1+\beta) \mathrm{T} / 2$. In this sense, the manufacturer prefers that the used market be as frictionless as possible.

The number of used cars that are held by their original owners in period $t$ is given by $\left(\tilde{\theta}_{1, \mathrm{t}-1}-\tilde{\theta}_{2, \mathrm{t}}\right) / 2$, which in steady state equals:

$$
\left(\tilde{\theta}_{1, t-1}-\tilde{\theta}_{2, t}\right) / 2=(1+\beta) T / 2\left(s_{1}-s_{2}\right) \cdot
$$

This measure is inversely related to the volume of trade in the second hand market. The greater the degree of imperfect substitutability between new and used durables, as reflected by the difference $\Delta=\mathrm{s}_{1}-\mathrm{s}_{2}$, the greater is the volume of secondhand trade. Recall that steady state output is a decreasing function of $s_{2}$, given our normalization that discounted service flows sum to one, and hence an increasing function of the difference $\Delta$. Therefore both the number and the fraction of new cars that are held by their original owner are decreasing in this difference. The greater the difference in service flows, the larger are the potential gains from trade between the heterogeneous consumers, and the more trade will occur. In contrast, the larger the transaction costs in the secondhand market, T, the greater are market frictions, and the lower the volume of trade in used durables.

The difference $\Delta$ measures the decline in services provided by the durable between the first and second periods of its life. If prices reflect the remaining discounted flow of services, then $\Delta$ will also be a measure of the convexity of the price sequence of the durable over time. That is, the greater is $\Delta$, the greater the difference between new and used durable prices in equilibrium. More generally, if a durable lasts longer than two periods, then its price sequence will be more convex the more rapidly service flows diminish over time.

In our model, the market clearing price of a used durable in period $t$ is determined by the participation constraint of consumers who are indifferent between buying a used good and being out of the market, 


$$
\mathrm{P}_{2, \mathrm{t}}=\mathrm{s}_{2} \tilde{\theta}_{3, \mathrm{t}}=\mathrm{s}_{2}\left(\Theta-\mathrm{Q}_{\mathrm{t}}-\mathrm{Q}_{\mathrm{t}-1}\right)
$$

Given our previous expression for the price of new goods in period $t$, we can solve for the implicit rental price of new durables in period $t$ :

$$
P_{1, t}-\beta P_{2, t+1}=s_{1}\left(\Theta-Q_{t}\right)-s_{2} Q_{t-1}-(1+\beta) T / 2 .
$$

The rental price is increasing in $\mathrm{s}_{1}$ and decreasing in $\mathrm{s}_{2}$, and so an increasing function of $\Delta$ $=\mathrm{s}_{1}-\mathrm{s}_{2}$. Hence, the greater is $\Delta$, the more convex the price sequence of the durable. A convex price sequence will have a relatively high implicit rental price in the first period.

Thus, the model with transaction costs in the secondhand market predicts that durable goods that retain their value better, in the sense of maintaining a flow of services, will have a less convex sequence of prices over time, and will trade less often on the secondhand market.

\section{Data}

In order to test the predictions of the model, automobile data from three sources have been collected. First, we obtained the title transfer history for individual vehicles from the Illinois Secretary of State. Second, average prices of used vehicles were obtained from the National Automobile Dealers Association. Finally, reliability data were obtained from Consumer Reports, which collects repair histories from its reader survey. Summary statistics are provided at the model/year level in their annual automobile issue. We now describe the data in more detail.

\section{Ownership History}

Title transaction histories provide information on the number and timing of trades in the used car market. The unit of observation is an individual vehicle. The Illinois Secretary of State (ILSS) provided data on all title transfers for a random sample of 250,000 passenger cars, pickup trucks, and sport utility vehicles in model years 1986 through 1989, inclusive. The sample period precedes the large scale leasing of new 
vehicles. The number of titles (OWNERS) and the date of each title transfer are recorded by the ILSS. Most vehicles had three or fewer owners in the sample period. The ILSS records the most recent 11 title transfers. The Vehicle Identification Number (VIN) is reported for each vehicle. This 17-digit number allows us to code vehicles into 760 model/year categories (approximately 190 per year), and we can follow vehicles across owners.

Many vehicles in the ILSS's random sample were eliminated from the data set for several reasons. First, we do not observe the initial purchase date if the title was transferred into the state. Second, some vehicles had coding errors in ILSS records. Third, we dropped the 1989 model year in order to have a relatively long price history. Fourth, some models had an insufficient number of observations, such as Alpha Romeo and Fiat. Finally, a sample selection bias exists for a subset of the 1986 vehicles. ${ }^{4}$ The remaining sample size is 104,033 vehicles.

The odometer reading at the time of the last transfer (ODOMETER) is also reported to the ILSS. ${ }^{5}$ A used car with high mileage should be an inferior substitute for a new vehicle compared to a car with low mileage. In order to control for this effect, we construct expected vehicle mileage, PREDOD, as a function of vintage and vehicle manufacturer. The variable ODDIF $=$ ODOMETER - PREDOD is the deviation from predicted mileage, in thousands of miles.

Table 1 presents some summary statistics for the title history data set. On average, vehicles had about two owners in the sample period. About a quarter of the vehicles in the sample are pickups, vans or sport utility vehicles, as indicated by the NOTCAR dummy. The BUSINESS, SINGLE and MARRIED dummy variables indicate

\footnotetext{
4 Title histories on 1986 model year vehicles purchased new before January 1, 1987, were included in the sample only if there was a subsequent transaction. Therefore, all 1986 model year vehicles that had an initial purchase date in 1986 were dropped from the data set.

5 The odometer reading is omitted for some vehicles and reported as zero. For other vehicles the odometer may have rolled over. There is a box on the title transfer form to indicate that the physical limits of the odometer have been exceeded, but its status is not recorded in the data set.
} 
whether the original registration was for a business, a single individual, or more than one person, respectively.

Table 2 displays the distribution of OWNERS, the number of owners, by model year. Almost half the vehicles, $46 \%$, were with their original owner at the end of the sample period. Very few had more than two title transfers, i.e., more than three owners. Vehicles in older model years are more likely to have more owners.

Table 3 lists summary statistics for the average number of OWNERS and sample sizes by manufacturer, where a "manufacturer" is a group of models (and more disaggregate than actual manufacturers). Vehicles from manufacturers with reputations for reliability, such as Acura, Honda, Mercedes, Saab, Toyota and Volvo, had relatively few title transfers. In contrast, there are more title transfers on average for AMC, Cadillac, Jaguar, Lincoln, Merkur, Porsche, Suzuki and Yugo. We also report the fraction of vehicles that were sold by the original owner by the end of the sample period. At this level, the title transfer data are consistent with the model sketched in section II, which predicts that cars that depreciate relatively quickly are more likely to be sold by their original owners.

\section{Price Data}

The monthly National Automobile Dealers Association (NADA) price books provide data that can be used to measure the resale value and substitutability over time of each model. NADA publishes 10 regional "Blue Books" (which are orange) monthly. The Central edition includes all of Illinois, except for one rural county. NADA generates average retail prices (RP) from sales reports provided by member dealers. Average wholesale prices (WP) are generated from sales reports from auto auctions, as well as dealer reports.

The reported Retail Price (RP) of a vehicle might be distorted if a trade-in is involved in the transaction. Because auto auctions do not have trade-ins associated with sales, the wholesale prices may be more reliable. Prices are sampled once per year, in 
December. The auto sale year begins in September of the previous year, and models are on the market for 12 to 15 months before the first December observation. NADA rounds prices to the nearest $\$ 25$. Each model/year pair has at least 7 years of price data. $\mathrm{RP}_{\mathrm{i}}$ and $\mathrm{WP}_{\mathrm{i}}$ denote the mean retail and wholesale prices, respectively, in the $\mathrm{i}^{\text {th }}$ sample year for each vehicle. For example, $\mathrm{WP}_{3}$ is the average wholesale price of a three-year-old car. Prices are normalized by dividing by $\mathrm{RP}_{1}$ and $\mathrm{WP}_{1}$ for each vehicle's retail and wholesale price series. ${ }^{6}$ We denote the normalized price measures as RPER ${ }_{\mathrm{i}}$ and $\mathrm{WPER}_{\mathrm{i}}$, respectively. They capture the fraction of a vehicle's initial used price that is retained at age i.

We do not capture the dramatic first year price depreciation experienced by new cars, since we do not observe the average price of new vehicles. List prices are available, but they are unreliable measures of actual transaction prices, as different manufacturers have different discount and rebate policies.

Transaction costs are estimated as the difference between the retail and wholesale prices for a four year old vehicle:

$$
\mathrm{TC}=\left(\mathrm{RP}_{4}-\mathrm{WP}_{4}\right)
$$

$\log (\mathrm{TC})$ is the natural logarithm of our measure of transaction costs. We use year 4 because it falls in the middle of the 7 years of observed prices.

As discussed in section II, in market equilibrium the first difference in price, or the fraction of value retained, is a function of the service flow from the good. A measure of the degree of substitutability is the second difference in the market price, or the first difference of the service flow. SUBST measures the convexity of the sequence of normalized wholesale prices. The period over which the service flow is measured is three years. Hence SUBST $=\left[\left(\mathrm{WP}_{1}-\mathrm{WP}_{4}\right)-\left(\mathrm{WP}_{4}-\mathrm{WP}_{7}\right)\right] / \mathrm{WP}_{1}=1-2 \mathrm{WPER}_{4}+\mathrm{WPER}_{7}$.

\footnotetext{
679 retail and wholesale prices were missing from a sample of 5,130. These 79 missing prices were estimated with a linear approximation that uses sample prices from 6 months and 12 months later. Let MP denote the missing price, P6 the price 6 months later, and P12 the price 12 months later. Then $\mathrm{MP}=\mathrm{P} 6+(\mathrm{P} 6-\mathrm{P} 12)$.
} 
The higher is SUBST, the more convex is the sequence of wholesale prices, and we infer that an older vehicle is a relatively poor substitute for its new counterpart. We use wholesale prices because they are probably more reliable than retail prices. However, we obtain similar empirical results when we use a SUBST measure based on retail prices.

Table 4 presents summary statistics for the NADA wholesale price data. On average, prices fall by $2 / 3$ between the end of the first and the seventh year on the market, as measured by $\mathrm{WPER}_{7}$. But there is considerable dispersion in this measure, as $\mathrm{WPER}_{7}$ ranges from .03 to .74 . In addition, our measure of the convexity of the price sequence over time relative to the one-year price, SUBST, also exhibits considerable dispersion.

\section{Quality Data}

Quality data permit us to gauge the reliability of a vehicle relative to its peers and to control for the different rates of physical depreciation. Consumer Reports collects survey data on the repair records of vehicles owned by subscribers. Based on the survey response, they publish a "Trouble Index" that indicates the reliability of each model/year over time. Like SUBST, this index measures whether older vehicles yield relatively high service flows, in comparison with their service flows when they were new.

Consumer Reports aggregates responses from a questionnaire on automobile performance in 16 different areas to generate their index. The Trouble Index is a relative measure, and reported on a five-point scale. Consumer Reports sets the cutoffs for the categories as follows:

Well Above Average: Overall reliability $35 \%$ or more above average (denoted WAA =1) Above Average: Overall reliability $15 \%$ to $35 \%$ above average $(\mathrm{AA}=1)$ Average: Overall reliability within $15 \%$ of average Below Average: Between $15 \%$ and $35 \%$ less than average $(\mathrm{BA}=1)$ Well Below Average: Overall reliability $35 \%$ or less than average $(\mathrm{WBA}=1)$

Approximately 15 percent of the Trouble Indices for 1987 to 1991 are not reported by Consumer Reports due to insufficient data. Half were omitted from the sample due to 
insufficient sample size (e.g., Alfa Romeo and Fiat). The remaining values were estimated using an ordered probit based on a manufacturer dummy and the vehicle's age.

Trouble Indices are highly collinear for different ages of a given model/year, as reliable cars generally remain reliable. Our empirical results consider only the Trouble Index at age four. We report average Trouble Indices by manufacturer in Table 3, where WAA corresponds to $\mathrm{TI}=0$, and $\mathrm{TI}=4$ for WBA model years.

\section{Empirical Results}

Our theoretical model predicts that the more imperfect a substitute a used vehicle is for a new model, the more trade there should be in the used market. This section reports on our tests of this hypothesis, as well as some related results.

We consider three different measures of trade in the used market: the number of owners (OWNERS), whether the original owner sold the vehicle within the sample period (TRADED $=1$ if OWNERS $>1$ ), and the duration of ownership (DURATION). In the tables described below, we first employ a least squares regression where the logarithm of OWNERS is the dependent variable. Second, a logistic regression is used to model the original owner's decision whether to sell their vehicle in the used market, i.e., whether TRADED equals one. Finally, we model the duration of ownership, where we account for the right censoring of the data for vehicles that are not sold by the end of the sample period. For example, an observation is censored if TRADED equals zero. DURATION is measured in days. The duration model assumes a Weibull distribution, which permits us to interpret the estimated coefficients as either Accelerated Failure Time (AFT) or Hazard models.

All estimates omit retained value (WPER) due to collinearity with the measure of substitutability. Our measure of substitutability, SUBST, is as defined above. Note that the unexpected mileage variable ODDIF will be zero for any new car that is not traded during our sample period, as there is no transaction that requires an odometer reading report to the ILSS. As a result, ODDIF is omitted in the TRADED equations. The 
omitted category of the Consumer Reports Trouble Index is "average". The natural logarithm of the first period wholesale price, $\mathrm{WP}_{1}$, is included to control for the absolute price level of the car. SINGLE and BUSINESS are dummy variables that indicate whether an individual or a business holds the title, respectively. The omitted category occurs when two or more individuals hold the title jointly.

The first columns of Table 5 present OLS estimates of the determinants of the number of OWNERS based on the full sample of all vehicles. The remaining columns report results for the subsample of vehicles that had two or more owners. We consider this subsample separately, to see whether the first sale of vehicle is distinctive, as might be predicted by an adverse selection model. In contrast, if the extent of quality deterioration is common knowledge, the forces governing the first decision whether and when to sell a vehicle should be similar to those governing subsequent sales. A vehicle is included in the "Purchased Used" subsample if the first owner sold it during the sample period. Here the least squares regression equation predicts the number of owners, given that there is more than one. The total number of vehicles in this subsample is 56,131.

The estimated coefficient for SUBST is consistent with our model's predictions and significant for both samples. If the pattern of used prices over time is relatively convex, which we interpret to indicate that a used vehicle is a relatively imperfect substitute for the same vehicle when purchased new, a vehicle has more owners on average.

According to the Consumer Reports reliability measures, unreliable vehicles (the BA and WBA categories) are traded more frequently, whereas reliable vehicles (WAA and AA) are traded less often.

The results also indicate that vehicles originally registered to a single individual are traded more often than are those registered to multiple owners, perhaps because we do not observe vehicle transfers within a family. Multiple registered owner households may be more likely to own more than one vehicle. The coefficient on BUSINESS indicates that vehicles with business owners are traded less often. 
The coefficient on the pick-up truck, SUV and van dummy, NOTCAR, indicates that they are traded less frequently than passenger cars. This is consistent with our model to the extent that service characteristics such the cargo carrying capacity or the benefits of four wheel drive, say, do not deteriorate over time. The $\log \left(\mathrm{WP}_{1}\right)$ coefficient indicates that expensive cars are also traded less frequently. This may occur because there is a correlation between initial price and overall vehicle quality. The sign on ODDIF is positive. High mileage cars are traded more frequently.

One result that is contrary to the predictions of our model is the effect of transaction costs, $\log (\mathrm{TC})$. Cars with high transaction costs, according to our measure, are traded more frequently. However, there appears to be a negative correlation between transaction costs and vehicle reliability. Cars that Consumer Reports rates as well above average or above average in reliability are traded infrequently and also have low transaction costs. The reason for the lower transaction costs on reliable vehicles could be because of lower pre-sale expenses such as inventory and preparation or lower warranty costs. $^{7}$

The specification reported in Table 6 reexamines the determinants of the number of owners by including a complete set of manufacturer dummies in the OLS estimation procedures. ${ }^{8}$ This specification focuses on within manufacturer variation. The SUBST coefficient is smaller than that in Table 5. That is, the within-manufacturer effect is smaller than that between manufacturers, but significant nonetheless. The ordering of the manufacturer coefficients is similar to the means reported in Table 3, and some of the effects are large. Lincolns have approximately $20 \%$ more owners, and Suzukis about 35\%. The other coefficients are similar to their counterparts in Table 5.

The first columns of Tables 7 and 8 present logit results for the determinants of whether a vehicle is TRADED by the original owner by the end of the sample period. The

\footnotetext{
${ }^{7}$ Many states require that a dealer offer a 30 or 90-day warranty on used vehicles.

8 The estimated coefficients for each manufacturer are not reported in Table 6.
} 
second set of columns report the determinants of whether the second owner, who purchased a used car, sold the vehicle before the end of the sample period (i.e., whether OWNERS $>2$, given that OWNERS $>1$ ). The regressions in Table 8 include a complete set of manufacturer dummies, as in Table 6.

The pattern of the coefficients in Tables 7 and 8 are similar to the analogous coefficients in Tables 5 and 6.

Finally, the first columns of Tables 9 and 10 report results from the duration model for the entire sample, with and without manufacturer fixed effects, respectively, where the likelihood function has a separate term for the ownership tenure of the original owner as well as all subsequent owners. A vehicle enters the likelihood function for the duration model multiple times if it was traded more than once, once for each time the car was traded in the second-hand market and once for the last owner in the sample period.

The second set of columns in tables 9 and 10 considers the determinants of the length of time the vehicle is held by the original owner, who "Purchased New." We again account for the censoring of those observations where the vehicle had only one owner in the sample period. Here each vehicle enters the likelihood function once.

The final set of columns in Tables 9 and 10 report results for the subsample of owners who acquired a used vehicle. In this instance, the likelihood function accounts for the duration of ownership for every titleholder after the original owner.

The coefficients in Tables 9 and 10 are similar to those in the preceding tables. For example, if the pattern of used prices over time is relatively convex, as indicated by a high value of SUBST, a vehicle has more owners, the original owner is more likely to sell, and the duration of ownership is shorter.

In order to test whether new and used car buyers behave similarly, we test whether the SUBST coefficients are equivalent for the various specifications. That is, we test whether the $\boldsymbol{\beta}_{\text {SUBST }}$ coefficients are equal for the subsamples of vehicles purchased new and used. The test statistics are reported in Table 11. The hypothesis that the SUBST 
coefficients are equal cannot be rejected for any of the specifications that include manufacturer fixed effects, nor for the OLS regressions reported in Table 5. The hypothesis that the SUBST coefficient is equal for new and used owners can be rejected for the logit and duration models without manufacturer fixed effects. Nevertheless, the determinants of trading activity are quite similar for the various subsamples and specifications considered.

\section{Conclusion}

Anecdotal evidence suggests that many transactions in secondhand durable markets occur when consumers with a relative preference for "newness" sell their older good in order to update their holdings. Earlier models of used durable markets have not emphasized this aspect of secondhand trade. Instead, the literature has considered trading patterns when sellers with private information seek to "unload" a good of inferior quality (Akerlof's lemons) or when there are exogenous changes in consumers' preferences (Bulow's baby carriage).

We model the market for secondhand durables as a vertically differentiated product space in which a good provides high quality when it is new and lower quality later in its life. Trade in the secondhand market occurs because consumers have heterogeneous preferences for quality and because the flow of services from a durable good diminishes as the durable ages. Our model predicts that vehicles that depreciate relatively quickly, as

reflected by their prices on the used car market, are traded relatively frequently. This prediction differs from that of a similar model that emphasizes adverse selection (Hendel and Lizzeri, 1997).

We test this prediction with a data set that records title transfers for 104,033 vehicles in Illinois over the period from 1986 to 1994. Our data set also includes average retail and wholesale prices and quality information. We employ three different measures of the volume of secondhand trade: the number of owners, whether individual vehicles are traded, and the duration of ownership. The estimated coefficients for SUBST, our measure of imperfect substitutability between older and new vehicles, are significant and 
have the predicted signs. The empirical results are robust across our three different measures of secondhand trade volume.

Our paper offers a different perspective on trade in used durables. We do not regard the empirical results as definitive, but they suggest that our model of secondhand trade has some empirical validity. Our theoretical analysis does not consider the possibility of leasing. If there are moral hazard issues associated with drivers not exercising proper care, then leasing will not be an attractive alternative for the manufacturer. However, in the model years following those in our sample, leasing has become a widespread phenomenon, and it would be interesting to see how the market for new and used cars has been affected.

\section{References}

Akerlof, G. (1970), “The Market for 'Lemons': Quality Uncertainty and the Market Mechanism,” Quarterly Journal of Economics, 84, 488-500.

Benjamin, D., and R. Kormendi (1974), “The Interrelationship between Markets for New and Used Durable Goods," Journal of Law and Economics, 17, 381-401.

Bond, E. (1982), “A Direct Test of the "Lemons” Model: The Market for Used Pickup Trucks," American Economic Review, 72, 836-840. (1983), “Trade in Used Equipment with Heterogeneous Firms,” Journal of Political Economy, 91, 688-705.

(1986), "The Effect of Used Markets with Endogenous Replacement of Durable Goods," Southern Economic Journal, 422-431. 
, and L. Samuelson (1984), "Durable Good Monopolies with Rational

Expectations and Replacement Sales," RAND Journal of Economics, 15, 336-345.

Bulow, J. (1982), “Durable Goods Monopolists,” Journal of Political Economy, 90, 314-332.

Coase, R. (1972), “Durability and Monopoly,” Journal of Law and Economics, 15, 143-149.

Fudenberg, D. and J. Tirole (1998), "Upgrades, Tradeins, and Buybacks," RAND Journal of Economics, 29, 235-258.

Genesove, D. (1992) "Adverse Selection in the Wholesale Used Car Market," Journal of Political Economy, 101, 644-665.

Greene, W. (1997), Econometric Analysis, $3^{\text {rd }}$ edition, Upper Saddle River: Prentice-Hall.

Hamilton, B. and M. Macauley (1998), "Competition and Car Longevity,” mimeo, Resources for the Future.

Hendel, I. and A. Lizzeri (1998), “Adverse Selection in Durable Goods Markets,” mimeo, Princeton University.

Hirshleifer, J. (1971), “Suppression of Inventions,” Journal of Political Economy, 79, 382-383.

Liebowitz, S. (1982), “Durability, Market Structure, and New-Used Goods Models," American Economic Review, 72, 816-824.

Miller, H. L. (1974), “On Killing off the Market for Used Textbooks and the Relationship between Markets for New and Secondhand Goods," Journal of Political Economy, 82, 612-619. 
Purohit, D. (1992), "Exploring the Relationship between the Markets for New and Used Durable Goods: The Case of Automobiles,” Marketing Science, 154-167.

Varian, H. (1997), “Buying, Sharing and Renting Information Goods,” mimeo, University of California at Berkeley.

Waldman, M. (1993), “A New Perspective on Planned Obsolescence,” Quarterly Journal of Economics, 108, 273-283. (1996), “Durable Goods Pricing when Quality Matters," Journal of Business, 69, 489-510. (1997), "Eliminating the Market for Secondhand Goods: An Alternative Explanation for Leasing," Journal of Law and Economics, 40, 61-92. 
Table 1

Summary Statistics of the Illinois Title History Data

\begin{tabular}{|c|c|c|c|c|}
\hline Variable & Mean & Std Deviation & Minimum & Maximum \\
\hline OWNERS & 1.922 & 1.117 & 1 & 11 \\
\hline ODDIF & -0.064 & 25.578 & -99.2 & 933.2 \\
\hline NOTCAR & 0.231 & 0.422 & 0 & 1 \\
\hline 1986 & 0.023 & 0.150 & 0 & 1 \\
\hline 1987 & 0.444 & 0.497 & 0 & 1 \\
\hline 1988 & 0.532 & 0.499 & 0 & 1 \\
\hline BUSINESS & 0.008 & 0.085 & 0 & 1 \\
\hline SINGLE & 0.591 & 0.492 & 0 & 1 \\
\hline MARRIED & 0.401 & 0.49 & 0 & 1 \\
\hline
\end{tabular}

Table 2

Distribution of Number of Owners by Model Year

\begin{tabular}{lrrrrrrrr}
\hline & \multicolumn{2}{c}{1986} & \multicolumn{2}{c}{1987} & \multicolumn{2}{c}{1988} & \multicolumn{2}{c}{ Total } \\
\hline $\begin{array}{l}\text { Number } \\
\text { of }\end{array}$ & $\begin{array}{c}\text { Number } \\
\text { of }\end{array}$ & $\begin{array}{c}\text { Fraction } \\
\text { of Model }\end{array}$ & $\begin{array}{c}\text { Number } \\
\text { of }\end{array}$ & $\begin{array}{l}\text { Fraction } \\
\text { of Model }\end{array}$ & $\begin{array}{c}\text { Number } \\
\text { of }\end{array}$ & $\begin{array}{c}\text { Fraction } \\
\text { of Model }\end{array}$ & $\begin{array}{c}\text { Number } \\
\text { of }\end{array}$ & $\begin{array}{c}\text { Fraction } \\
\text { of Total }\end{array}$ \\
Owners & $\begin{array}{r}\text { Vehicles } \\
1\end{array}$ & \multicolumn{1}{c}{ Year } & Vehicles & Year & Vehicles & Year & Vehicles & \\
2 & 1,025 & 0.426 & 19,197 & 0.415 & 27,680 & 0.500 & 47,902 & 0.460 \\
3 & 616 & 0.256 & 14,303 & 0.309 & 15,944 & 0.288 & 30,863 & 0.297 \\
4 or 5 & 419 & 0.174 & 7,580 & 0.164 & 7,596 & 0.137 & 15,595 & 0.150 \\
6 to 11 & 301 & 0.084 & 4,551 & 0.072 & 3,760 & 0.052 & 8,612 & 0.061 \\
Total & 46 & 0.041 & 600 & 0.026 & 415 & 0.016 & 1,061 & 0.021 \\
\hline
\end{tabular}


Table 3

Summary Statistics by Manufacturer

\begin{tabular}{|c|c|c|c|c|}
\hline Manufacturer & Observations & Mean \# of Owners & Fraction Traded & Average Trouble Index \\
\hline$\overline{\text { ACURA }}$ & 608 & 1.681 & 0.461 & 0.000 \\
\hline $\mathrm{AMC}$ & 116 & 2.405 & 0.672 & 4.000 \\
\hline AUDI & 264 & 1.920 & 0.538 & 1.655 \\
\hline BMW & 428 & 1.874 & 0.528 & 1.820 \\
\hline BUICK & 5,785 & 1.879 & 0.545 & 2.883 \\
\hline CADILLAC & 2,386 & 2.034 & 0.618 & 2.051 \\
\hline CHEVY & 20,671 & 1.940 & 0.537 & 2.751 \\
\hline CHRYSLER & 2,355 & 1.966 & 0.585 & 2.946 \\
\hline DODGE & 6,448 & 1.887 & 0.525 & 2.712 \\
\hline FORD & 20,058 & 1.973 & 0.558 & 2.791 \\
\hline GMC & 1702 & 1.826 & 0.506 & 3.266 \\
\hline HONDA & 3,752 & 1.678 & 0.425 & 0.054 \\
\hline HYUNDAI & 922 & 2.008 & 0.518 & 4.000 \\
\hline ISUZU & 269 & 1.914 & 0.539 & 1.290 \\
\hline JAGUAR & 158 & 1.975 & 0.582 & 3.994 \\
\hline JEEP_EAG & 832 & 2.017 & 0.565 & 2.153 \\
\hline LINCOLN & 1,693 & 2.209 & 0.689 & 1.967 \\
\hline MAZDA & 1,620 & 1.804 & 0.473 & 0.596 \\
\hline MERCEDES & 582 & 1.777 & 0.483 & 0.880 \\
\hline MERCURY & 4,289 & 1.932 & 0.562 & 2.151 \\
\hline MERKUR & 106 & 2.226 & 0.642 & 4.000 \\
\hline MITSUBISHI & 426 & 2.059 & 0.587 & 1.031 \\
\hline NISSAN & 3,009 & 1.983 & 0.540 & 1.096 \\
\hline OLDS & 7,118 & 1.855 & 0.534 & 2.533 \\
\hline PEUGEOT & 30 & 1.900 & 0.533 & 4.000 \\
\hline PLYMOUTH & 4,343 & 1.953 & 0.556 & 2.308 \\
\hline PONTIAC & 6,341 & 2.028 & 0.582 & 3.235 \\
\hline PORSCHE & 154 & 1.903 & 0.519 & 2.000 \\
\hline SAAB & 253 & 1.731 & 0.451 & 2.328 \\
\hline SUBARU & 594 & 1.714 & 0.458 & 1.419 \\
\hline SUZUKI & 142 & 2.676 & 0.775 & 0.000 \\
\hline TOYOTA & 4,618 & 1.759 & 0.464 & 0.515 \\
\hline VOLVO & 601 & 1.542 & 0.381 & 1.418 \\
\hline VW & 1,030 & 1.721 & 0.448 & 2.220 \\
\hline YUGO & 330 & 2.188 & 0.545 & 4.000 \\
\hline Total & 104,033 & 1.941 & 0.541 & 2.173 \\
\hline
\end{tabular}


Table 4

Summary Statistics of the N.A.D.A. Wholesale Price Data

\begin{tabular}{lrrrr}
\hline Variable & Mean & Std Dev & Minimum & \multicolumn{1}{r}{ Maximum } \\
\hline WP1 & 9,277 & 3,823 & 2,600 & 51,025 \\
WP2 & 8,047 & 3,496 & 1,250 & 46,125 \\
WP3 & 6,717 & 3,011 & 850 & 39,950 \\
WP4 & 5,565 & 2,598 & 625 & 34,600 \\
WP5 & 4,660 & 2,345 & 100 & 30,375 \\
WP6 & 3,948 & 2,234 & 100 & 31,250 \\
WP7 & 3,090 & 1,908 & 100 & 26,250 \\
WPER1 & 1.000 & 0.000 & 1.000 & 1.000 \\
WPER2 & 0.862 & 0.061 & 0.459 & 1.169 \\
WPER3 & 0.718 & 0.086 & 0.317 & 1.042 \\
WPER4 & 0.591 & 0.098 & 0.199 & 0.890 \\
WPER5 & 0.491 & 0.110 & 0.037 & 0.839 \\
WPER6 & 0.412 & 0.121 & 0.037 & 0.785 \\
WPER7 & 0.330 & 0.118 & 0.033 & 0.740 \\
SUBST & 0.148 & 0.132 & -0.223 & 0.712 \\
\hline
\end{tabular}


Table 5

OLS Estimation of the Determinants of the Number of Owners Without Manufacturer Fixed Effects

\begin{tabular}{lrrrrrr}
\hline & \multicolumn{3}{c}{ Purchased New } & \multicolumn{3}{c}{ Purchased Used } \\
\hline \multicolumn{1}{c}{ Variable } & \multicolumn{1}{c}{ Est. } & Std. Err. & Est./S.E. & \multicolumn{1}{l}{ Est. } & Std. Err. & Est./S.E. \\
Constant & 0.1245 & 0.0602 & 2.0661 & 1.0358 & 0.0482 & 21.4691 \\
SUBST & 0.1715 & 0.0216 & 7.9273 & 0.1452 & 0.0177 & 8.1995 \\
Log(WP) & -0.1091 & 0.0154 & -7.0633 & -0.0897 & 0.0120 & -7.4601 \\
NOTCAR & -0.0361 & 0.0050 & -7.2046 & -0.0122 & 0.0040 & -3.0335 \\
SINGLE & 0.1146 & 0.0033 & 35.1356 & 0.0463 & 0.0027 & 16.9343 \\
BUSINESS & -0.3550 & 0.0180 & -19.6802 & -0.1642 & 0.0313 & -5.2551 \\
1986 & 0.1673 & 0.0118 & 14.1882 & 0.1269 & 0.0095 & 13.3917 \\
1987 & 0.1100 & 0.0038 & 28.7513 & 0.0447 & 0.0032 & 14.1692 \\
log(TC) & 0.1719 & 0.0226 & 7.6179 & 0.0893 & 0.0175 & 5.0944 \\
WAA & -0.0638 & 0.0056 & -11.3072 & -0.0118 & 0.0048 & -2.4589 \\
AA & -0.0667 & 0.0066 & -10.0405 & -0.0266 & 0.0057 & -4.7035 \\
BA & 0.0118 & 0.0043 & 2.7724 & $3.01 \mathrm{E}-4$ & 0.0035 & 0.0863 \\
WBA & 0.0390 & 0.0044 & 8.8509 & 0.0206 & 0.0036 & 5.7841 \\
ODDIF & 0.0020 & $6.22 \mathrm{E}-5$ & 31.8211 & $3.58 \mathrm{E}-4$ & $3.86 \mathrm{E}-5$ & 9.2866 \\
Number of & & 104,033 & & & 56,131 & \\
Observations & & & & & & 0.019 \\
R Squared & & 0.042 & & & & \\
\hline
\end{tabular}


Table 6

OLS Estimation of the Determinants of the Number of Owners With Manufacturer Fixed Effects

\begin{tabular}{|c|c|c|c|c|c|c|}
\hline \multirow[b]{2}{*}{ Variable } & \multicolumn{3}{|c|}{ Purchased New } & \multicolumn{3}{|c|}{ Purchased Used } \\
\hline & Est. & Std. Err. & Est./S.E. & Est. & Std. Err. & Est./S.E. \\
\hline Constant & 0.3160 & 0.0886 & 3.5682 & 1.1850 & 0.0706 & 16.7933 \\
\hline SUBST & 0.1020 & 0.0270 & 3.7735 & 0.0770 & 0.0219 & 3.5213 \\
\hline $\log (\mathrm{WP})$ & -0.0991 & 0.0168 & -5.8934 & -0.0790 & 0.0131 & -6.0480 \\
\hline NOTCAR & -0.0387 & 0.0059 & -6.5118 & -0.0169 & 0.0048 & -3.5420 \\
\hline SINGLE & 0.1138 & 0.0033 & 34.9292 & 0.0452 & 0.0027 & 16.5237 \\
\hline BUSINESS & -0.3568 & 0.0181 & -19.7603 & -0.1669 & 0.0312 & -5.3473 \\
\hline 1986 & 0.1551 & 0.0126 & 12.3398 & 0.1162 & 0.0101 & 11.5213 \\
\hline 1987 & 0.1076 & 0.0041 & 26.1574 & 0.0412 & 0.0034 & 12.2336 \\
\hline $\log (\mathrm{TC})$ & 0.1296 & 0.0249 & 5.2008 & 0.0530 & 0.0192 & 2.7646 \\
\hline WAA & -0.0352 & 0.0077 & -4.5866 & -0.0185 & 0.0065 & -2.8427 \\
\hline $\mathrm{AA}$ & -0.0524 & 0.0082 & -6.4177 & -0.0386 & 0.0069 & -5.6048 \\
\hline BA & 0.0115 & 0.0045 & 2.5754 & -0.0013 & 0.0037 & -0.3431 \\
\hline WBA & 0.0354 & 0.0047 & 7.5190 & 0.0165 & 0.0038 & \\
\hline ODDIF & 0.0020 & $6.20 \mathrm{E}-5$ & 31.9671 & $3.62 \mathrm{E}-4$ & $3.85 \mathrm{E}-5$ & 9.4026 \\
\hline Number of & & 104,033 & & & 56,131 & \\
\hline Observations & & & & & & \\
\hline R Squared & & 0.048 & & & 0.023 & \\
\hline
\end{tabular}


Table 7

Logit Estimation of Whether a Vehicle is Traded Without Manufacturer Fixed Effects

\begin{tabular}{|c|c|c|c|c|c|c|}
\hline \multirow[b]{2}{*}{ Variable } & \multicolumn{3}{|c|}{ Purchased New } & \multicolumn{3}{|c|}{ Purchased Used } \\
\hline & Est. & Std. Err & Est./S.E. & Est. & Std. Err. & Est./S.E. \\
\hline Constant & -2.018 & 10.2458 & -8.2103 & -0.0374 & 0.3241 & -0.1154 \\
\hline SUBST & 0.4582 & 0.0876 & 5.2306 & 0.7823 & 0.1180 & 6.6297 \\
\hline $\log (\mathrm{WP})$ & -0.2860 & 0.0664 & -4.3072 & -0.4426 & 0.0848 & -5.2193 \\
\hline NOTCAR & -0.1298 & 80.0206 & -6.3010 & -0.0632 & 0.0272 & -2.3235 \\
\hline SINGLE & 0.4046 & 0.0129 & 31.364 & 0.2649 & 0.0180 & 14.717 \\
\hline BUSINESS & $-1.965 £$ & 0.1083 & -18.151 & -1.3745 & 0.2814 & -4.8845 \\
\hline 1986 & 0.3786 & 0.0471 & 8.0382 & 0.6614 & 0.0621 & 10.651 \\
\hline 1987 & 0.3698 & 0.0152 & 24.329 & 0.2300 & 0.0207 & 11.111 \\
\hline $\log (\mathrm{TC})$ & 0.6034 & 0.0979 & 6.1634 & 0.4770 & 0.1247 & 3.8252 \\
\hline WAA & -0.258 & 40.0224 & -11.536 & -0.0783 & 0.0316 & -2.4778 \\
\hline AA & $-0.242 \varepsilon$ & 80.0263 & -9.2319 & -0.1907 & 0.0375 & -5.0853 \\
\hline BA & 0.0521 & 0.0170 & 3.0647 & 0.0069 & 0.0229 & 0.3017 \\
\hline WBA & 0.1099 & 0.0176 & 6.2443 & 0.0928 & 0.0232 & 4.0000 \\
\hline $\begin{array}{l}\text { Number of } \\
\text { Observations }\end{array}$ & & 104,033 & & & 56,131 & \\
\hline Log Likelihood & & $-70,360$ & & & $-38,299$ & \\
\hline
\end{tabular}


Table 8

Logit Estimation of Whether a Vehicle is Traded With Manufacturer Fixed Effects

\begin{tabular}{lrrrrrr}
\hline & \multicolumn{3}{c}{ Purchased New } & \multicolumn{3}{c}{ Purchased Used } \\
\hline \multicolumn{1}{c}{ Variable } & \multicolumn{1}{c}{ Est. } & \multicolumn{1}{c}{ Std. Err. } & Est./S.E. & \multicolumn{1}{c}{ Est. } & \multicolumn{1}{c}{ Std. Err. Est./S.E. } \\
Constant & -1.5626 & 0.3632 & -4.3023 & 0.8152 & 0.4673 & 1.7445 \\
SUBST & 0.3150 & 0.1103 & 2.8558 & 0.3756 & 0.1443 & 2.6029 \\
Log(WP) & -0.2686 & 0.0720 & -3.7306 & -0.3680 & 0.0875 & -4.2057 \\
NOTCAR & -0.1269 & 0.0244 & -5.2008 & -0.0926 & 0.0316 & -2.9304 \\
SINGLE & 0.4071 & 0.0130 & 31.315 & 0.2606 & 0.0180 & 14.478 \\
BUSINESS & -1.9580 & 0.1085 & -18.046 & -1.3908 & 0.2815 & -4.9407 \\
1986 & 0.3535 & 0.0505 & 7.0000 & 0.5924 & 0.0664 & 8.9217 \\
1987 & 0.3696 & 0.0165 & 22.400 & 0.2080 & 0.0222 & 9.3694 \\
log(TC) & 0.5093 & 0.1088 & 4.6811 & 0.2530 & 0.1293 & 1.9567 \\
WAA & -0.1087 & 0.0306 & -3.5523 & -0.0792 & 0.0429 & -1.8462 \\
AA & -0.1472 & 0.0327 & -4.5015 & -0.2460 & 0.0457 & -5.3829 \\
BA & 0.0549 & 0.0179 & 3.0670 & 0.0064 & 0.0241 & 0.2664 \\
WBA & 0.1030 & 0.0189 & 5.4497 & 0.0754 & 0.0248 & 3.0403 \\
Number of & & 104,033 & & & 56,131 & \\
Observations & & & & & & $-38,205$ \\
Log Likelihood & & $-70,068$ & & & \\
\hline
\end{tabular}


Table 9

\section{Determinants of the Duration of Ownership Without Manufacturer Fixed Effects}

\begin{tabular}{|c|c|c|c|c|c|c|c|c|c|}
\hline \multirow[b]{2}{*}{ Variable } & \multicolumn{3}{|c|}{ All Transactions } & \multicolumn{3}{|c|}{ Purchased New } & \multicolumn{3}{|c|}{ Purchased Used } \\
\hline & Est. & Std. Err. & Est./S.E. & Est. & Std. Err. & Est./S.E. & Est. & Std. Err. & Est./S.E. \\
\hline Constant & 5.2256 & 0.1298 & 40.2592 & 6.0556 & 0.1438 & 42.1248 & 3.0266 & 0.2061 & 14.6855 \\
\hline SUBST & -0.4914 & 0.0453 & -10.8374 & -0.3211 & 0.0508 & -6.3188 & -0.5340 & 0.0723 & -7.3881 \\
\hline $\log (\mathrm{WP})$ & 0.2968 & 0.0349 & 8.5074 & 0.2096 & 0.0399 & 5.2556 & 0.2701 & 0.0504 & 5.3621 \\
\hline NOTCAR & 0.0786 & 0.0110 & 7.1623 & 0.0923 & 0.0122 & 7.5514 & 0.0046 & 0.0173 & 0.2679 \\
\hline SINGLE & -0.2736 & 0.0071 & -38.7933 & -0.2012 & 0.0077 & -26.2124 & -0.2953 & 0.0119 & -24.8062 \\
\hline BUSINESS & 1.7545 & 0.0958 & 18.3090 & 1.4614 & 0.0879 & 16.6310 & 1.1936 & 0.2632 & 4.5355 \\
\hline 1986 & -0.2376 & 0.0227 & -10.4813 & -0.0968 & 0.0264 & -3.6646 & -0.2488 & 0.0352 & -7.0717 \\
\hline 1987 & -0.1139 & 0.0080 & -14.3022 & -0.0841 & 0.0088 & -9.5773 & -0.0308 & 0.0132 & -2.3250 \\
\hline $\log (\mathrm{TC})$ & -0.4321 & 0.0518 & -8.3345 & -0.4370 & 0.0591 & -7.3966 & -0.1331 & 0.0745 & -1.7858 \\
\hline WAA & 0.1378 & 0.0124 & 11.1404 & 0.1566 & 0.0136 & 11.5353 & 0.0182 & 0.0205 & 0.8881 \\
\hline AA & 0.1621 & 0.0146 & 11.0859 & 0.1655 & 0.0159 & 10.4190 & 0.0655 & 0.0247 & 2.6566 \\
\hline BA & -0.0232 & 0.0089 & -2.6005 & -0.0274 & 0.0098 & -2.7928 & -0.0040 & 0.0148 & -0.2709 \\
\hline WBA & -0.0857 & 0.0089 & -9.6071 & -0.0584 & 0.0100 & -5.8691 & -0.0874 & 0.0145 & -6.0105 \\
\hline ODDIF & -0.0023 & $7.50 \mathrm{E}-5$ & -30.2400 & -0.0027 & $7.60 \mathrm{E}-5$ & -35.1763 & $-3.38 \mathrm{E}-4$ & $1.54 \mathrm{E}-4$ & -2.1948 \\
\hline SHAPE & 1.0246 & 0.0029 & 356.5040 & 0.8660 & 0.0034 & 258.1103 & 1.0840 & 0.0046 & 237.6771 \\
\hline \begin{tabular}{l|} 
Number of \\
Observations \\
Censored \\
Observations \\
Log Likelihood
\end{tabular} & & $\begin{array}{r}95,870 \\
-238,125\end{array}$ & & & $\begin{array}{r}47,902 \\
-128,659\end{array}$ & & & $-105,316$ & \\
\hline
\end{tabular}


Table 10

Determinants of the Duration of Ownership With Manufacturer Fixed Effects

\begin{tabular}{|c|c|c|c|c|c|c|c|c|c|}
\hline \multirow[b]{2}{*}{ Variable } & \multicolumn{3}{|c|}{ All Transactions } & \multicolumn{3}{|c|}{ Purchased New } & \multicolumn{3}{|c|}{ Purchased Used } \\
\hline & Est. & Std. Err. & Est./S.E. & Est. & Std. Err. & Est./S.E. & Est. & Std. Err. & Est./S.E. \\
\hline Constant & 4.7032 & 0.1909 & 24.6430 & 5.5589 & 0.2158 & 25.7641 & 3.0889 & 0.2954 & 10.4575 \\
\hline SUBST & -0.2844 & 0.0575 & -4.9480 & -0.1897 & 0.0645 & -2.9420 & -0.3503 & 0.0909 & -3.8557 \\
\hline $\log (\mathrm{WP})$ & 0.2569 & 0.0381 & 6.7409 & 0.1806 & 0.0439 & 4.1097 & 0.2353 & 0.0548 & 4.2972 \\
\hline NOTCAR & 0.0831 & 0.0129 & 6.4172 & 0.0833 & 0.0146 & 5.7176 & 0.0412 & 0.0201 & 2.0494 \\
\hline SINGLE & -0.2704 & 0.0071 & -38.3316 & -0.1988 & 0.0077 & -25.8792 & -0.2914 & 0.0119 & -24.4426 \\
\hline BUSINESS & 1.7568 & 0.0957 & 18.3553 & 1.4560 & 0.0878 & 16.5803 & 1.2020 & 0.2631 & 4.5691 \\
\hline 1986 & -0.2010 & 0.0244 & -8.2226 & -0.0690 & 0.0283 & -2.4326 & -0.2294 & 0.0381 & -6.0236 \\
\hline 1987 & -0.1051 & 0.0086 & -12.2706 & -0.0804 & 0.0095 & -8.4858 & -0.0234 & 0.0141 & -1.6552 \\
\hline $\log (\mathrm{TC})$ & -0.3023 & 0.0580 & -5.2145 & -0.3261 & 0.0670 & -4.8659 & -0.0888 & 0.0813 & -1.0919 \\
\hline WAA & 0.0744 & 0.0164 & 4.5305 & 0.0574 & 0.0180 & 3.1919 & 0.0612 & 0.0276 & 2.2161 \\
\hline AA & 0.1442 & 0.0177 & 8.1645 & 0.1090 & 0.0193 & 5.6568 & 0.1268 & 0.0297 & 4.2680 \\
\hline BA & -0.0195 & 0.0094 & -2.0828 & -0.0291 & 0.0103 & -2.8209 & 0.0061 & 0.0155 & 0.3912 \\
\hline WBA & -0.0751 & 0.0096 & -7.8596 & -0.0549 & 0.0107 & & -0.0724 & 0.0155 & -4.6616 \\
\hline ODDIF & -0.0023 & $7.40 \mathrm{E}-5$ & -30.4405 & -0.0026 & $7.50 \mathrm{E}-5$ & -35.1093 & $-3.40 \mathrm{E}-4$ & $1.53 \mathrm{E}-04$ & -2.2216 \\
\hline SHAPE & 1.0227 & 0.0029 & 356.726 & 0.8646 & 0.0033 & 258.383 & 1.0836 & 0.0046 & 237.674 \\
\hline \begin{tabular}{l|} 
Number of \\
Observations \\
Censored \\
Observations \\
Log Likelihood
\end{tabular} & & 199,903 & & & 104,033 & & & $-105,231$ & \\
\hline
\end{tabular}


Table 11

Test of Equality of SUBST Coefficients for New and Used Vehicles

Without Manufacturer Fixed Effects

\begin{tabular}{|l|c|c|c|}
\hline Dependent Variable & $\begin{array}{c}\text { Ownership Duration } \\
\text { (Table 9) }\end{array}$ & $\begin{array}{c}\text { Decision to Trade } \\
\text { (Table 7) }\end{array}$ & $\begin{array}{c}\text { Number of Owners } \\
\text { (Table 5) }\end{array}$ \\
\hline Type of Test & Wald & Likelihood Ratio & F-Test \\
\hline Test Statistic & 5.807 & 4.871 & 0.669 \\
\hline P-value & 0.016 & 0.027 & 0.413 \\
\hline
\end{tabular}

With Manufacturer Fixed Effects

\begin{tabular}{|l|c|c|c|}
\hline Dependent Variable & $\begin{array}{c}\text { Ownership Duration } \\
\text { (Table 10) }\end{array}$ & $\begin{array}{c}\text { Decision to Trade } \\
\text { (Table 8) }\end{array}$ & $\begin{array}{c}\text { Number of Owners } \\
\text { (Table 6) }\end{array}$ \\
\hline Type of Test & Wald & Likelihood Ratio & F-Test \\
\hline Test Statistic & 2.077 & 0.118 & 0.395 \\
\hline P-value & 0.150 & 0.731 & 0.530 \\
\hline
\end{tabular}


Figure 1

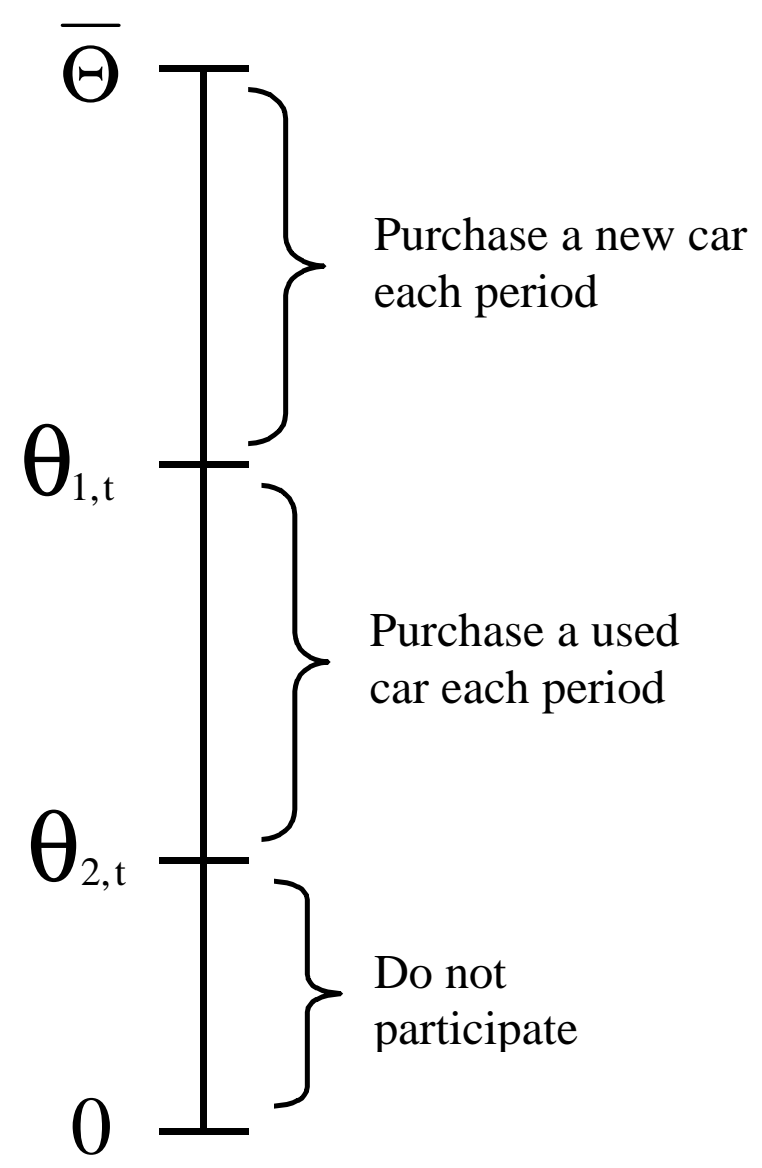


Figure 2

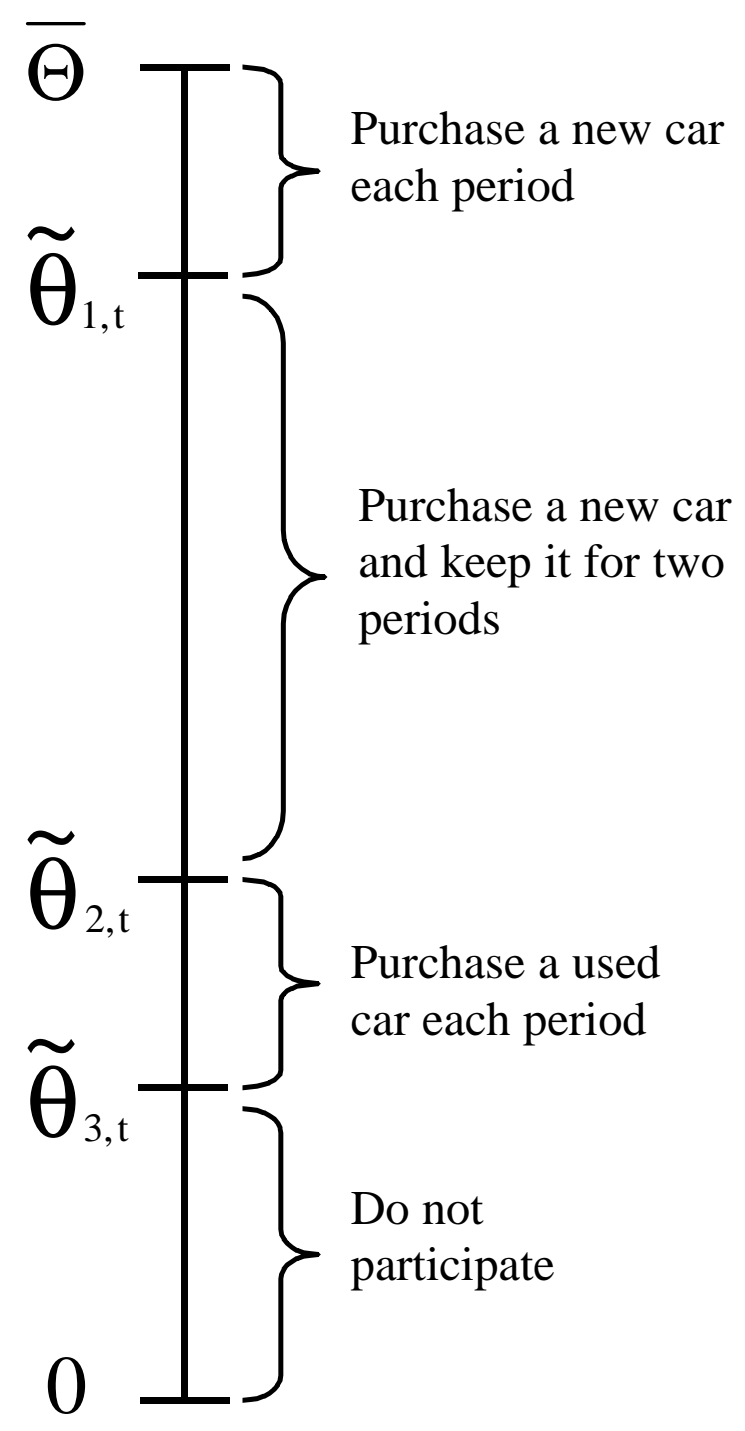

